\title{
НЕОБХІДНІСТЬ ОРГАНІЗАЦІЇ ДИСТАНЦІЙНИХ ФОРМ ПРАЦІ БУХГАЛТЕРІЇ ТА СУДОВИХ ЕКСПЕРТІВ БУХГАЛТЕРСЬКОГО І ПОДАТКОВОГО ОБЛІКІВ В УСТАНОВАХ ДЕРЖАВНОГО СЕКТОРА
}

\section{THE NEED TO ORGANIZE REMOTE FORMS OF WORK FOR ACCOUNTING AND FORENSIC EXPERTS ACCOUNTING AND TAX ACCOUNTING IN PUBLIC SECTOR INSTITUTIONS}

\author{
Дмитрук Борис Пахомович \\ кандидат економічних наук, професор, \\ Східноєвропейський університет імені Рауфра Аблязова \\ ORCID: https://orcid.org/0000-0002-6179-9923 \\ Гріднєва Дар'я Вікторівна \\ кандидат економічних наук, доцент, \\ Східноєвропейський університет імені Рауфра Аблязова \\ ORCID: https://orcid.org/0000-0002-0879-3493 \\ Светлова Ніна Миколаївна \\ старший викладач, \\ Східноєвропейський університет імені Рауфра Аблязова \\ ORCID: https://orcid.org/0000-0002-6600-4894

\section{Dmytruk Borys, Hridnieva Daria, Svetlova Nina \\ Rauf Ablyazov East European University}

\begin{abstract}
Досліджені сучасні проблеми невідповідності чинного трудового законодавства, опрацьовані нові положення, закони, зміни внесені у законодавство після переведення на дистанційну (надомну) роботу бухгалтерів, судових експертів бухгалтерського, податкового обліків в установах державного сектора. Проаналізовані традиційні способи та розглянута модель організації дистанційної праці бухгалтерів та судових експертів бухгалтерського, податкового обліків в установах державного сектора щодо запобігання поширенню COVID-19 в Україні, а також документальне оформлення: переведення працівників на нові умови праці, оплати праці, матеріально-технічної відповідальності. Проаналізовані правила переведення на дистанційні умови праці судових експертів державних спеціалізованих установ і судових експертів, які у таких установах не працюють. Розглянуто правове регулювання змін порядку здійснення електронного документообігу установ державного сектора та державних спеціалізованих установ в умовах запобігання поширенню COVID-19 в Україні.

Ключові слова: судовий експерт бухгалтерського і податкового обліків, дистанційна форма праці, правове регулювання, трудове законодавство, зберігання матеріалів справ, установи державного сектора.
\end{abstract}

Исследованы современные проблемы несоответствия действующего трудового законодательства, обработаны новые положения, законы, изменения внесенные в законодательство после перевода на дистанционную (надомную) работу бухгалтеров и судебных экспертов бухгалтерского, налогового учетов в учреждениях государственного сектора. Проанализированы традиционные способы и рассмотрена модель организации дистанционного труда бухгалтеров и судебных экспертов бухгалтерского, налогового учетов в учреждениях государственного сектора по предотвращению распространения COVID-19 в Украине, а также документальное оформление перевода работников на новые условия труда, оплаты труда, материально-технической ответственности. Проанализированы правила перевода на дистанционные условия труда судебных экспертов государственных специализированных учреждений и судебных экспертов, которые в таких учреждениях не работают. Рассмотрено правовое регулирование изменений порядка осуществления электронного документооборота учреждений государственного сектора и госу- 
дарственных специализированных учреждений в условиях предотвращения распространения COVID-19 в Украине.

Ключевые слова: судебный эксперт по бухгалтерскому и налоговому учету, дистанционной фрорме работы, Правовому регулированию, трудовому законодательству, хранению материалов дел, учреждениям государственного сектора.

Modern problems of non-compliance with the current labor legislation are investigated, new provisions and laws are worked out, and changes were made to the legislation after accountants and forensic experts of accounting and tax accounting in public sector institutions were transferred to remote (home-based) work. The article analyzes traditional methods and considers the model of organizing remote work of accountants and forensic experts of Accounting, Tax Accounting in public sector institutions to prevent the spread of COVID-19 in Ukraine, as well as documentation: transfer of employees to new working conditions; remuneration; material and technical responsibility. Generalized conclusions regarding: the work of employees of certain categories outside public sector institutions during the quarantine period, the need for employers to recognize remote (home-based) work as one of the types of Labor Relations and their compliance with the requirements of the legislation of Ukraine. Organizational and methodological support and qualitative basis depends on the approach to the formation of a theoretical basis for forensic examination of accounting and tax accounting. For a case that is being investigated by the bodies of inquiry, pre-trial and judicial investigation, the following are crucial: a clear organization and methodology of forensic expertise, the quality and reliability of the formed expert research conclusion. The article analyzes the rules for transferring forensic experts of State specialized institutions to remote working conditions in comparison with forensic experts who do not work in such institutions. The absence of changes in the regulation of the procedure at the legislative level, storage of case materials and objects of expert research outside the office premises, transfer of forensic experts of accounting and tax records to a remote form of work during quarantines and lockdowns was revealed. The legal regulation of changes in the procedure for electronic document management of public sector institutions and state specialized institutions in the context of preventing the spread of COVID-19 in Ukraine is considered.

Keywords: forensic expert of accounting and tax accounting, remote form of Work, Legal Regulation, labor legislation, storage of case materials, public sector institutions.

Постановка проблеми. В умовах запобігання поширенню COVID-19, введення карантинів і локдаунів, в Україні виникла необхідність в організації дистанційної форми праці судових експертів бухгалтерського і податкового обліків в установах державного сектора. Виявлені проблеми невідповідності чинного трудового законодавства сучасним реаліям і застосування його норм у надзвичайних ситуаціях. 3 метою не допущення призупинення господарської діяльності та зменшення зараження працівників, установи державного сектора були вимушені приймати нестандартні рішення і запроваджувати дистанційну (надомну) форми роботи. Такі працівники виконували свої обов'язки в домашніх умовах, якщо їх присутність на робочому місці була не обов'язковою. Трудове законодавство не містить такого поняття, як віддалена чи дистанційна робота. Найбільш наближеною до такого режиму була надомна робота, умови якої регулювалися чинним Кодексом законів про працю (далі КЗпП) та Положенням про умови праці надомників, затвердженими постановою Держкомпраці СРСР і Секретаріату ВЦРПС від 29.09.81 р. № 275/17-99, яке $\epsilon$ чинним у частині, що не суперечить Конституції та законам України, а також колективним та трудовим угодам. 3 метою належного врегулювання трудового законодавства було прийнято низку змін і доповнень. Розпорядження і накази не містять вказівок та розрахунків на компенсацію працівникам вартості зносу домашньої техніки, витрат комунальних послуг установами державного сектора, понесених під час дистанційної роботи.

Аналіз останніх досліджень і публікацій. Проблеми державного регулювання дистанційної фрорми праці не знаходить широкого висвітлення у наукових колах, але сучасні тенденції свідчать про необхідність досліджень у цій сорері. Зокрема, теоретичними та методичними проблемами дистанційної форми праці займались такі науковці, як Вонберг Т., Ковшова І., Кузнецова М., Сільченко С. Досліджень саме організації дистанційної фрорми праці в установах державного сектору в умовах запобігання поширенню COVID-19 в Україні, на сьогодні не проводилося.

Виділення невирішених раніше частин загальної проблеми - 3 метою запобігання поширенню COVID-19 в Україні бухгалтерам та судовим експертам бухгалтерського і податкового обліків, установам державного сектора необхідно переходити на дистанційну форму праці. На сьогодні існує суттєва різниця в умовах проведення судової експертизи судовими експертами бухгалтерського і податкового обліків державних спеціалізованих установ, яка полягає в забороні зберігання справ i 
об'єктів експертизи поза межами службових приміщень. На відміну від судових експертів, які не працюють у державних спеціалізованих установах, але мають право здійснювати судово-експертну діяльність у приміщенні, придатному для проведення досліджень, зберігання доказів, документів діловодства та наглядових проваджень.

Формулювання цілей статті. Дослідити проблеми невідповідності чинного трудового законодавства сучасним реаліям і запровадження його норм у надзвичайних ситуаціях в Україні - карантинів і локдаунів. Провести аналіз напрямків, змін, доповнень, внесених у законодавство для організації переведення на дистанційну (надомну) роботу судових експертів бухгалтерського і податкового обліку. Вивчити питання доцільності правового регулювання змін в електронному документообігу державних спеціалізованих установ для запобігання поширенню COVID-19 в Україні. Проаналізувати умови, правила переведення на дистанційну форму праці судових експертів державних спеціалізованих установ в порівнянні із умовами приватних судових експертів, які там не працюють.

Виклад основного матеріалу. Пандемія COVID-19 внесла корективи в усі ссрери життєдіяльності. На період карантину урядом введені жорсткі обмеження у вигляді карантинів і локдаунів, які призвели до серйозних економічних наслідків: було заборонено працювати більшості не критично важливих підприємств, установ в тому числі у сорері торгівлі, масові зібрання, закрито транспортне сполучення. Бізнес змушений переводити співробітників на віддалену роботу, відправляти їх в неоплачувану відпустку і зменшувати ставки.

3 метою запобігання поширенню COVID-19, спричиненої коронавірусом SARS-CoV-2 та на виконання постанови Кабінету Міністрів України від 11.03.2020 р. № 211 керівникам державних установ рекомендовано перевести більшість своїх працівників на дистанційну роботу [10]. 3 метою пом'якшення наслідків для економіки країни і підтримки громадян в період пандемії Верховна Рада України прийняла два ключові закони 18 і 30 березня 2020 р., спрямовані на підтримку бізнесу: Закон № 530-ІХ [7] і Закон № 540-ІХ [6]. Кабінет Міністрів України та інші органи виконавчої і місцевої влади також прийняли деякі рішення в сорері трудових відносин.

Для врегулювання питання дистанційної роботи до трудового законодавства Законом від 30.03.2020 № 530-ІХ [7]. Відповідно до пп. 1 п. 2 Закону № 530 на період встановлення карантину або обмежувальних заходів, пов'язаних із поширенням коронавірусної хвороби, роботодавець може доручити працівникові, зокрема службовцю державному і органів місцевого самоврядування, виконувати протягом певного періоду роботу вдома, визначену трудовою угодою. Можливість запровадження гнучких режимів зумовлена нормами ст. 13 КЗпП та ст. 7 Закону № 3356, згідно 3 якими питання режиму роботи, тривалості робочого часу і відпочинку є предметом регулювання колективного договору [4]. КЗпП не враховані окремі аспекти застосування гнучкого грасріку, тому Мінсоцполітики України розроблено рекомендації № 359, в яких викладено умови та порядок запровадження графріку з урахуванням норм законодавства [4]. Національне агентство з питань державної служби надало роз'яснення від 20.03.2020 р. № 87-р/3 щодо впровадження змін до Правил [16]. 3 27.02.2021 р. в Україні діють нові правила віддаленої роботи, запроваджені два її види - дистанційна і надомна, нові форми угод діють з 16.07.2021р., укладаються за типовими форматами у письмовому вигляді.

Впровадження дистанційної моделі роботи судових експертів бухгалтерського і податкового обліків установ державного сектора ґрунтується на чинних нормативно-правових актах. Так, в установах державного сектора, за умов карантину, працівники переводяться на дистанційну форму роботи в домашніх умовах, якщо специфріка установи дає змогу застосувати такий формат. До організації дистанційної роботи в установах державного сектора відносяться питання 3 оплати праці, матеріально-технічного забезпечення [4], які можна організувати вдома за двома варіантами: користування технікою судового експерта; роботодавець забезпечує працівника технікою. За першим варіантом, користування технікою працівника, він повинен письмово повідомити установу державного сектора, про те, що для дистанційної роботи в нього $€$ необхідні технічні засоби та програмне забезпечення і він погоджується їх використовувати, налаштовуючи своє робоче місце за допомогою сервісів доступу до віддаленого робочого столу установи. У такому випадку працівнику будуть доступні всі ресурси, які були в нього на робочому місці для проведення судових експертиз. Такий варіант роботи не призводить до змін у бухгалтерському обліку, оскільки жодного переміщення 
активів не відбувається. За другим варіантом, техніку надає роботодавець, забезпечення судового експерта бухгалтерського і податкового обліків засобами праці шляхом передачі обладнання з установи державного сектора для роботи вдома. При цьому керівник установи на підставі окремого розпорядження чи наказу, повинен затвердити перелік технічного обладнання і осіб, яким воно передано для виконання службових обов'язків.

Передача працівникам установи державного сектора для дистанційної роботи техніки, яка обліковується в бюджетному обліку у складі основних засобах (на субрахунку 1014 «Машини та обладнання», 1016 «Інструменти, прилади, інвентар», 1018 «Інші основні засоби») або інших необоротних матеріальних активах (на субрахунку 1118 «нші необоротні матеріальні активи»), малоцінних необоротних матеріальних активах (на субрахунку 1113 «Малоцінні необоротні матеріальні активи»), офрормляється 3 застосуванням акту внутрішнього переміщення основних засобів за передбаченою формою [11]. При цьому, в бухгалтерському обліку, за тимчасової передачі активів у користування працівникам, структурних змін не відбувається. Такі переміщення відображаються тільки в аналітичному обліку установ державного сектора, на передані основні засоби та інші необоротні матеріальні активи продовжують нараховувати амортизацію.

На відміну від приватного сектора економіки, організацію дистанційної роботи працівників в установах державного сектора регламентовано відповідними центральними і місцевими органами влади. Кабінет Міністрів України рекомендував центральним та іншим державним органам, органам місцевого самоврядування, установам державного сектора, підприємствам, установам, організаціям на час дії карантину забезпечити працівникам, позмінну роботу, за можливості - віддалену роботу в режимі реального часу через Інтернет [10]. Органи влади видали свої законодавчі і правозастосовні акти для запобігання поширенню коронавірусу: наказ Міносвіти від 16.03.2020 р. № 406 [13]; розпорядження КМДА від 16.03.2020 р. № 444 [8]; наказ НАДС від 16.03.2020 р. № 40-20 [9]. Ст. 125 КЗпП (у редакції Закону України від 30.09.2020 р. № 931-IX) передбачено право працівника на розрахунок компенсації для отримання від роботодавця за знос (амортизацію) власних інструментів, задіяних для робочих потреб [4].

Обов'язковою умовою застосування гнучких режимів $є$ забезпечення обліку відпрацьо- ваного робочого часу й контролю за трудовою дисципліною персоналу в даному режимі, необхідно: розробити систему контролю та обліку робочого часу працівника, який працюватиме за гнучким графріком. Робота в умовах гнучких режимів може бути організовано за такими варіантами: поденний та підсумковий облік робочого часу. Тривалість робочого часу (зміни) в умовах гнучкого режиму не повинна перевищувати 12 год на добу. Технологічний процес судової експертизи поєднує живу працю працівників, засоби праці (технічне забезпечення обліку), специсрічні предмети праці: бухгалтерські документи, облікові регістри, фрінансову та податкову звітності (табл. 1).

При цьому, можна застосовувати й змішану модель роботи судових експертів - дистанційну і звичайну. Вважаємо, що переведення на дистанційну форму роботи судових експертів бухгалтерського і податкового обліку в державних спеціалізованих установах повинно ґрунтуватися на специфріці їх діяльності. Судова експертиза бухгалтерського та податкового обліку належить до найпоширеніших видів судових експертиз (надалі - судова експертиза). Ії̈ застосовують при розслідуванні та розгляді кримінальних і цивільних справ, коли виникають питання, для розв'язання яких необхідні спеціальні знання з бухгалтерського та податкового обліку, звітності, аналізу фрінансово-господарської діяльності підприємства. Об'єктом судової експертизи є документи, бухгалтерські реєстри, бухгалтерська і податкова звітність, в якій відображена господарська діяльність підприємств. Відповідно до інструкції про призначення та проведення судових експертиз та експертних досліджень судова експертиза бухгалтерського, податкового обліку і звітності $\epsilon$ складовою економічної експертизи [2].

Судовими експертами державних спеціалізованих установ можуть бути фрахівці, які мають відповідну вищу освіту, освітньо-кваліфікаційний рівень не нижче спеціаліста, пройшли відповідну підготовку та отримали кваліфрікацію судового експерта з певної спеціальності [14]. Кваліфрікація судового експерта фрахівцям науково-дослідних установ судових експертиз Міністерства юстиції України присвоюється за додатком 5, а - фрахівцям, що не працюють у державних спеціалізованих установах за додатком 6 [4]. Атестовані відповідно судові експерти включаються до державного Реєстру атестованих судових експертів, ведення якого покладається на Міністерство юстиції України [14]. Зокрема, судова експер- 
Таблиця 1

Порівняння моделей традиційної і дистанційної роботи судових експертів в установах державного сектора

\begin{tabular}{|c|c|c|}
\hline Елемент моделі & Традиційна модель & Дистанційна модель \\
\hline \multicolumn{3}{|c|}{ Облікові працівники і судові експерти бухгалтерського та податкового обліку: } \\
\hline режим роботи & встановлюється установою & $\begin{array}{l}\text { встановлюється самостійно } \\
\text { але не більше } 40 \text { годин } \\
\text { на тиждень }\end{array}$ \\
\hline посадові обов'язки & виконуються на робочому місці & виконуються дистанційно \\
\hline трудова дисципліна & $\begin{array}{l}\text { регулюється правилами } \\
\text { внутрішнього трудового розпорядку } \\
\text { (далі ПВТР) }\end{array}$ & $\begin{array}{l}\text { ПВТР потребують змін щодо } \\
\text { дистанційної фрорми роботи }\end{array}$ \\
\hline \multicolumn{3}{|c|}{ Засоби праці: } \\
\hline робоче місце & B odpici & вдома чи в іншому місці \\
\hline технічне забезпечення & $\begin{array}{l}\text { надається установою (комп'ютер, } \\
\text { принтер, фракс) }\end{array}$ & можуть бути власними \\
\hline програмне забезпечення & $\begin{array}{l}\text { традиційний пакет залежно від } \\
\text { специфріки роботи бухгалтерії та } \\
\text { судових експертів бухгалтерського } \\
\text { та податкового обліку }\end{array}$ & $\begin{array}{l}\text { необхідність використовувати } \\
\text { програмні продукти для } \\
\text { дистанційної роботи }\end{array}$ \\
\hline комунікаційні канали & особисто або комунікаційний канал & комунікаційний канал \\
\hline засоби захисту даних & $\begin{array}{l}\text { системи контролю доступу } \\
\text { та безпеки даних }\end{array}$ & $\begin{array}{l}\text { системи контролю доступу } \\
\text { та безпеки даних }\end{array}$ \\
\hline наявність Інтернету & контролюється установою & контролюється самостійно \\
\hline хмарне сховище & не обов'язкове & $\begin{array}{l}\text { обов'язкове, за особливими } \\
\text { вимогами і обставинами }\end{array}$ \\
\hline \multicolumn{3}{|c|}{ Специфічні предмети праці: } \\
\hline документообіг & паперовий, електронний & $\begin{array}{l}\text { розширити електронний } \\
\text { документообіг }\end{array}$ \\
\hline
\end{tabular}

тиза бухгалтерського та податкового обліку застосовується у процесі розслідування або судового розгляду справ про: розкрадання та привласнення майна, інші корисливі господарські злочини [2]. Отже, суттєва різниця (табл. 2) в умовах проведення судово-експертної діяльності судовими експертами, які працюють у державних спеціалізованих установах полягає в забороні зберігання справ i об'єктів експертизи поза межами службових приміщень, на відміну від судового експерта, який не працює у державних спеціалізованих установах і має право здійснювати судовоекспертну діяльність у приміщенні, придатному для проведення досліджень, зберігання доказів, документів діловодства та наглядових проваджень.

3 метою переведення судових експертів бухгалтерського і податкового обліків на дистанційну роботу під час карантинів і локдаунів, в законодавчі нормативні документи зміни не вносились. Законодавство встановлює, що судові експертизи по кримінальних і цивільних справах призначаються в тих випадках, коли для вирішення питань при провадженні за такими справами необхідні спеціальні пізнання. Правове регулювання змін в організації судової експертизи, порядок здійснення електронного документообігу (електронний документ, цифровий підпис, цифрова печатка та інше) та можливість працівників судових експертів виконувати свої обов'язки у дистанційний спосіб, рекомендовано розробити ряд внутрішніх документів: Положення «Про електронні документи», Положення «Про порядок дистанційної роботи працівниками», робочі інструкції, інструкції 3 діловодства, накази та інше.

Багато підприємств, установ і організацій для робочих цілей, використовують захищені віртуальні мережі - VPN. Якщо співробітнику потрібна програма для підключення до VPN, необхідно налаштувати зв'язок 3 віддаленим робочим столом установи державного сектора. Тим, хто не зможе зробити це самостійно, знадобиться програма на зразок TeamViewer. За її допомогою адміністратор зможе підключити робоче місце віддалено. Засоби, які забезпечують інфрормаційну безпеку - антивірусні програми і DLP-системи. DLP - це програми, які відстежують: рух 
Таблиця 2

Порівняння умов, правил до переведення на дистанційну роботу судових експертів державних спеціалізованих установ та тих, які у таких установах не працюють

\begin{tabular}{|c|c|}
\hline \multicolumn{2}{|c|}{ Умови проведення судово-експертної діяльності } \\
\hline $\begin{array}{l}\text { судовими експертами, які працюють } \\
\text { у державних спеціалізованих установах }\end{array}$ & $\begin{array}{l}\text { судовими експертами, що не працюють } \\
\text { у державних спеціалізованих установах }\end{array}$ \\
\hline $\begin{array}{l}\text { Судовому експерту забороняється: } \\
\text { 1) передоручати проведення експертизи } \\
\text { іншій особі; } \\
\text { 2) самостійно збирати матеріали, які } \\
\text { підлягають дослідженню, а також вибирати } \\
\text { вихідні дані для проведення експертизи, } \\
\text { якщо вони відображені в наданих иому } \\
\text { матеріалах неоднозначно; } \\
\text { 3) вирішувати питання, які виходять за } \\
\text { межі спеціальних знань експерта, а також } \\
\text { для з'ясування питань права і надавати } \\
\text { оцінку законності проведення процедур, } \\
\text { регламентованих нормативно-правовими } \\
\text { актами; } \\
\text { 4) вступати у не передбачені порядком } \\
\text { проведення експертизи контакти з особами, } \\
\text { якщо такі особи прямо чи опосередковано } \\
\text { зацікавлені в результатах експертизи; } \\
\text { Заборонено: } \\
\text { - зберігати матеріали справ та об'єкти } \\
\text { експертних досліджень поза службовим } \\
\text { приміщенням [2]. }\end{array}$ & $\begin{array}{l}\text { Судовий експерт здійснює судово-експертну } \\
\text { діяльність у приміщенні, придатному для } \\
\text { проведення досліджень, зберігання доказів, } \\
\text { документів діловодства та наглядових } \\
\text { проваджень. } \\
\text { Приміщення повинно бути захищеним від } \\
\text { несанкціонованого проникнення відповідними } \\
\text { засобами реагування шляхом встановлення } \\
\text { охоронної сигналізації. } \\
\text { Не допускається розміщення робочого місця } \\
\text { судового експерта у тимчасових спорудах. } \\
\text { Робоче місце судового експерта розміщується } \\
\text { у приміщенні, яке захищене засобами } \\
\text { несанкціонованого проникнення від } \\
\text { приміщення, в якому здійснюють професійну } \\
\text { діяльність особи, діяльність яких не пов'язана } \\
\text { з судово-експертною діяльністю. } \\
\text { Біля входу в приміщення розміщується інфрор- } \\
\text { маційна вивіска, що ідентифікує приміщення } \\
\text { судового експерта, а також інфрормація щодо } \\
\text { часу початку та закінчення робочого дня, часу } \\
\text { обідньої перерви, вихідних днів [1]. }\end{array}$ \\
\hline
\end{tabular}

інфрормації в мережах, зберігання конфріденційних фрайлів на комп'ютері, переписку співробітників з конкурентами в месенджері. В основному ці системи використовуються в рамках офрісу, але ніщо не заважає застосовувати їх і для контролю співробітників, які працюють дистанційно. Це можливо вирішити за одним 3 двох варіантів. Перший - коли співробітник забирає свій робочий комп'ютер додому, і на ньому вже встановлений агент DLP-системи. Агент через інтернет підключається до центрального серверу і виконує свою роботу. Другий - коли співробітник підключається до віддаленого робочого столу комп'ютера установи державного сектора, захищеного DLP-системою. Тоді всі операції з інфрормацією відбуваються на ньому, а свій особистий комп'ютер працівник використовує тільки як термінал доступу. В процесі роботи можуть виникати питання щодо дотримання закону про захист персональних даних, тому не варто змушувати співробітників встановлювати систему на особисті комп'ютери.

Варто наголосити на створенні умов для есрективної комунікації при організації дистанційної роботи. Для спілкування використовуються месенджери, а також чати корпоративних порталів, на кшталт Бітрікс. Телеоронний зв'язок можна здійснювати за допомогою сер- вісів IP-телефронії, Скайп, Viber. Спільну роботу можна виконувати в Google документах і таблицях або в аналогічних сервісах. 3 урахуванням високих швидкостей сучасного інтернету проблем обміну навіть великими фрайлами не має.

В умовах, що склалися актуалізується питання використання хмарових сховищ інфрормації для зберігання облікових та інших даних. Це гарантія, на випадок пошкодження або втрати фрізичного носія, збереження інорормації. Хмарну інфрраструктуру варто оцінювати за наступними критеріями: система шифрування, алгоритм дій у разі збою, простоту керування, спеціальні пропозиції [15].

Висновки. Проблеми невідповідності чинного трудового законодавства сучасним реаліям застосування його норм у надзвичайних ситуаціях запровадження в Україні карантинів і локдаунів, оперативно вирішувалися, шляхом: удосконалення, змін, доповнення законодавчо - нормативної бази для переведення на дистанційну форму роботи працівників. Досліджені традиційні способи і розглянута сучасна модель організації дистанційної форми праці бухгалтерів та судових експертів бухгалтерського і податкового обліків в установах державного сектора, державних спеціалізованих установ в умовах запобігання поширенню COVID-19 в Україні, в тому числі 
і документальне офрормлення: переведення працівника на нові умови праці, оплати праці, матеріально-технічної відповідальності.

Зважаючи на вимоги сьогодення, робота працівників окремих категорій поза межами установ державного сектора в карантинний період $є$ однією з актуальних, при цьому, роботодавцям необхідно враховувати, що дистанційна (надомна) робота $є$ одним з видів трудових відносин і повинна відповідати вимогам законодавства України. Обґрунтований підхід до формування теоретичної бази для судової експертизи бухгалтерського і податкового обліків створює якісне підґрунтя ії організаційнометодичного забезпечення. Чітка організація і методика судової експертизи, якість, достовірність сорормованого висновку експертного дослідження мають вирішальне значення для справи, яка знаходиться у провадженні органів дізнання, досудового і судового слідства.

Результати проведеного порівняння показали суттєву різницю в умовах проведення судової експертизи судовими експертами бухгалтерського і податкового обліків державних спеціалізованих установ у частині заборони зберігання справ і об'єктів експертизи поза межами службових приміщень, на відміну від судових експертів, які не працюють у цих установах та мають право здійснювати судово-експертну діяльність у приміщенні, придатному для проведення досліджень, зберігання доказів, документів діловодства і наглядових проваджень. Сьогодні не внесені зміни в законодавчо-нормативні документи з питань щодо переведення судових експертів бухгалтерського і податкового обліків державних установ під час карантинів і локдаунів на дистанційну форму.

Порядок здійснення електронного документообігу (електронний документ, цифровий підпис, цифррова печатка та інше) та можливість працівників бухгалтерської служби і судових експертів виконувати свої обов'язки у дистанційний спосіб необхідно прописувати в наказі про облікову політику установи.

\section{СПИСОК ВИКОРИСТАНИХ ДЖЕРЕЛ:}

1. Інструкція про особливості здійснення судово-експертної діяльності атестованими судовими експертами, що не працюють у державних спеціалізованих експертних установах : Наказ Міністерства юстиції України від 12.12.2011 p. № 3505/5. URL: https://zakon.rada.gov.ua/laws/show/z1431-11\#Text (дата звернення: 29.07.2021).

2. Інструкція про призначення та проведення судових експертиз та експертних досліджень : Наказ Міністерства юстиції України від 08.10.1998 р. № 53/5. URL: https://zakon.rada.gov.ua/laws/show/z0705-98\#Text (дата звернення: 29.07.2021).

3. Інтернет-форум Freelance Today. 10 альтернатив TeamViewer. URL: https://freelance.today/poleznoe/10alternativ-teamviewer.html (дата звернення: 29.07.2021).

4. Кодекс законів про працю України : Кодекс України від 10.12.1971 p. № 322-VIII. URL: https://zakon.rada.gov.ua/ laws/show/322-08\#Tеxt (дата звернення: 03.08.2021).

5. Положення про Центральну експертно-кваліфікаційну комісію при Міністерстві юстиції України та атестацію судових експертів : Наказ Міністерства юстиції України від 03.03.2015 р. № 301/5. URL: https://zakon.rada.gov.ua/laws/show/z0249-15\#Text (дата звернення: 03.08.2021).

6. Про внесення змін до деяких законодавчих актів України, спрямованих на забезпечення додаткових соціальних та економічних гарантій у зв'язку з поширенням коронавірусної хвороби (COVID-19) : Закон України від 30.03.2020 p. № 540-IX. URL: https://zakon.rada.gov.ua/laws/show/540-20\#Text (дата звернення: 03.08.2021).

7. Про внесення змін до деяких законодавчих актів України, спрямованих на запобігання виникненню і поширенню коронавірусної хвороби (COVID-19) : Закон України від 17.03.2020 р. № 530-IX. URL: https://zakon.rada.gov.ua/laws/show/530-20\#Tеxt (дата звернення: 03.08.2021).

8. Про деякі заходи щодо запобігання поширенню коронавірусу COVID-19 на території міста Києва : Розпорядження КМДА від 16.03.2020 р. № 444. URL: https://kyivcity.gov.ua/npa/pro_deyaki_zakhodi_schodo_ zapobigannya_poshirennyu_koronavirusu_COVID-19_na_teritori_mista_kiyeval (дата звернення: 03.08.2021).

9. Про додаткові заходи з протидії поширенню на території України гострої респіраторної хвороби COVID-19, спричиненої коронавірусом SARS-CoV-2, в НАДC : Наказ Міністерства України з питань державної служби від 16.03.2020 p. № 40-20. URL: https://ips.ligazakon.net/document/FN060423 (дата звернення: 03.08.2021).

10.Про запобігання поширенню на території України гострої респіраторної хвороби COVID-19, спричиненої коронавірусом SARS-CoV-2 : Постанова Кабінету міністрів України від 11.03 .2020 р. № 211. URL: https://zakon.rada.gov.ua/laws/show/211-2020-\%D0\%BF\#Text (дата звернення: 03.08.2021).

11. Про затвердження типових форм 3 обліку та списання основних засобів суб'єктами державного сектора та порядку їх складання : Наказ Міністерства фрінансів України від 13.09.2016 р. № 818 . URL: https://zakon.rada.gov.ua/laws/show/z1336-16\#Text (дата звернення: 03.08.2021). 
12. Про затвердження типових фрорм трудових договорів про надомну та дистанційну роботу : Наказ Міністерства розвитку економіки, торгівлі та сільського господарства України від 05.05.2021 р. № 913-21. URL: http://search.ligazakon.ua/l_doc2.nsf/link1/RE36508.html (дата звернення: 03.08.2021).

13. Про організаційні заходи для запобігання поширенню коронавірусу COVID-19 : Наказ Міністерства освіти і науки України від 16.03.2020 р. № 406. URL: https://zakon.rada.gov.ua/rada/show/v0406729-20\#Text (дата звернення: 03.08.2021).

14. Про судову експертизу : Закон України від 25.02.1994 р. № 4038-XII. URL: https://zakon.rada.gov.ua/laws/ show/4038-12\#Tехt (дата звернення: 03.08.2021).

15. Топ-11 хмарних сховищ + Відеоогляд. URL: https://blog.comfy.ua/ua/top-11-khmarnikh-skhovishhvideooglyad-blog-comfy_a0-125/ (дата звернення: 29.07.2021).

16. Щодо впровадження змін до Правил внутрішнього службового розпорядку в органі державної влади (для виконання завдань за посадою віддалено) : Роз'яснення Національного агентства України з питань державної служби від 20.03.2020 p. № 87-p/3. URL: https://blog.comfy.ua/ua/top-11-khmarnikh-skhovishhvideooglyadblog-comfy_a0-125/ (дата звернення: 29.07.2021).

\section{REFERENCES:}

1. Instrukciya pro osoblivosti zdijsnennya sudovo-ekspertnoyi diyalnosti atestovanimi sudovimi ekspertami, sho ne pracyuyut u derzhavnih specializovanih ekspertnih ustanovah: Nakaz M-va yusticiyi Ukrayini 12.12.2011 r. № 3505/5 [Instruction on the peculiarities of carrying out forensic activities by certified forensic experts who do not work in state specialized expert institutions [electronic resource]: Order of the Ministry of Justice of Ukraine No. 3505/5 of 12.12.2011]. Retrieved from: https://zakon.rada.gov.ua/laws/show/z1431-11\#Text (accessed 29 July 2021).

2. Instrukciya pro priznachennya ta provedennya sudovih ekspertiz ta ekspertnih doslidzhen: Nakaz M-va yusticiyi Ukrayini 08.10.1998 r. № 53/5 [Instructions on the appointment and conduct of forensic examinations and expert studies [electronic resource]: Order of the Ministry of Justice of Ukraine No. 53/5 of 08.10.1998]. Retrieved from: https://zakon.rada.gov.ua/laws/show/z0705-98\#Text (accessed 29 July 2021).

3. Internet-forum Freelance Today. 10 alternativ TeamViewer. Retrieved from: https://freelance.today/ poleznoe/10-alternativ-teamviewer.html (accessed 29 July 2021).

4. Kodeks zakoniv pro pracyu Ukrayini: Kodeks Ukrayini vid 10.12.1971 r. № 322-VIII [Labor Code of Ukraine No. 322-VIII of 10.12.1971]. Retrieved from: https://zakon.rada.gov.ua/laws/show/322-08\#Text (accessed 03 August 2021).

5. Polozhennya pro Centralnu ekspertno-kvalifikacijnu komisiyu pri Ministerstvi yusticiyi Ukrayini ta atestaciyu sudovih ekspertiv: Nakaz M-va yusticiyi Ukrayini vid 03.03.2015 r. № 301/5 [Regulations on the Central Expert Qualification Commission under the Ministry of Justice of Ukraine and certification of forensic experts [electronic resource]: Order of the Ministry of Justice of Ukraine No. 301/5 of 03.03.2015]. Retrieved from: https://zakon.rada.gov.ua/laws/ show/z0249-15\#Text (accessed 03 August 2021).

6. Pro vnesennya zmin do deyakih zakonodavchih aktiv Ukrayini, spryamovanih na zabezpechennya dodatkovih socialnih ta ekonomichnih garantij u zv'yazku z poshirennyam koronavirusnoyi hvorobi (COVID-19): Zakon Ukrayini vid 30.03.2020 r. № 540-IX [On amendments to certain legislative acts of ukraine aimed at providing additional social and economic guarantees in connection with the spread of coronavirus disease (COVID-19) [electronic resource]: Law of Ukraine No. 540-IX of 30.03.2020]. Retrieved from: https://zakon.rada.gov.ua/laws/show/540-20\#Text (accessed 03 August 2021).

7. Pro vnesennya zmin do deyakih zakonodavchih aktiv Ukrayini, spryamovanih na zapobigannya viniknennyu i poshirennyu koronavirusnoyi hvorobi (COVID-19): Zakon Ukrayini vid 17.03.2020 r. № 530-IX [On amendments to certain legislative acts of Ukraine aimed at preventing the occurrence and spread of coronavirus disease (COVID-19) [electronic resource]: Law of Ukraine No. 530-IX of 17.03.2020]. Retrieved from: https://zakon.rada.gov.ua/laws/ show/530-20\#Text (accessed 03 August 2021).

8. Pro deyaki zahodi shodo zapobigannya poshirennyu koronavirusu COVID-19 na teritoriyi mista Kiyeva: Rozporyadzhennya KMDA vid 16.03.2020 r. № 444 [About some measures to prevent the spread of coronavirus COVID-19 in the city of Kyiv (COVID-19) [electronic resource]: Order of the Kyiv City State Administration No. 444 of 16.03.2020]. Retrieved from: https://kyivcity.gov.ua/npa/pro_deyaki_zakhodi_schodo_zapobigannya_poshirennyu_koronavirusu_COVID-19_na_teritori_mista_kiyeva/ (accessed 03 August 2021).

9. Pro dodatkovi zahodi z protidiyi poshirennyu na teritoriyi Ukrayini gostroyi respiratornoyi hvorobi COVID-19, sprichinenoyi koronavirusom SARS-CoV-2, v NADS: Nakaz M-va Ukrayini z pitan derzhavnoyi sluzhbi vid 16.03.2020 r. № 40-20 [On additional measures to counteract the spread of acute respiratory disease COVID-19 caused by coronavirus SARS-CoV-2 in Ukraine, in the NAPS [electronic resource]: Order of the Ministry of Ukraine on Civil Service No. 40-20 of 16.03.2020]. Retrieved from: https://ips.ligazakon.net/document/FN060423 (accessed 03 August 2021). 
10. Pro zapobigannya poshirennyu na teritoriyi Ukrayini gostroyi respiratornoyi hvorobi COVID-19, sprichinenoyi koronavirusom SARS-CoV-2: Postanova Kabinetu ministriv Ukrayini vid 11.03.2020 r. № 211 [On prevention of the spread on the territory of Ukraine of the acute respiratory disease COVID-19 caused by the coronavirus SARS-CoV-2 [electronic resource]: Order of the Ministry of Ukraine on Civil Service No. 211 of 11.03.2020]. Retrieved from: https://zakon.rada.gov.ua/laws/show/211-2020-\%D0\%BF\#Text (accessed 03 August 2021).

11. Pro zatverdzhennya tipovih form z obliku ta spisannya osnovnih zasobiv sub'yektami derzhavnogo sektoru ta poryadku yih skladannya: Nakaz M-va finansiv Ukrayini vid 13.09.2016 r. № 818 [On approval of standard forms for accounting and write-off of fixed assets by public sector entities and the procedure for their compilation [electronic resource]: Order of the Ministry of Finance of Ukraine No. 818 of 13.09.2016]. Retrieved from: https://zakon.rada.gov.ua/laws/show/ z1336-16\#Text (accessed 03 August 2021).

12. Pro zatverdzhennya tipovih form trudovih dogovoriv pro nadomnu ta distancijnu robotu: Nakaz M-va rozvitku ekonomiki, torgivli ta silskogo gospodarstva Ukrayini vid 05.05.2021 r. № 913-21 [On approval of standard forms of employment contracts for home and remote work [electronic resource]: Order of the Ministry of Economic Development, Trade and Agriculture of Ukraine No. 913-21 of 05.05.2021]. Retrieved from: http://search.ligazakon.ua/ I_doc2.nsf/link1/RE36508.html (accessed 03 August 2021).

13. Pro organizacijni zahodi dlya zapobigannya poshirennyu koronavirusu COVID-19: Nakaz M-va osviti i nauki Ukrayini vid 16.03.2020 r. № 406 [About organizational measures to prevent the spread of coronavirus COVID-19 [electronic resource]: Order of the Ministry of Education and Science of Ukraine No. 406 of 16.03.2020]. Retrieved from: https://zakon.rada.gov.ua/rada/show/v0406729-20\#Text (accessed 03 August 2021).

14. Pro sudovu ekspertizu: Zakon Ukrayini vid 25.02.1994 r. № 4038-XII [About forensic examination [electronic resource]: Law of Ukraine No. 4038-XII of 25.02.1994]. Retrieved from: https://zakon.rada.gov.ua/laws/ show/4038-12\#Text (accessed 03 August 2021).

15. Top-11 hmarnih shovish + Videooglyad. Retrieved from: https://blog.comfy.ua/ua/top-11-khmarnikh-skhovishhvideooglyad-blog-comfy_a0-125/(accessed 29 July 2021).

16. Shodo vprovadzhennya zmin do Pravil vnutrishnogo sluzhbovogo rozporyadku v organi derzhavnoyi vladi (dlya vikonannya zavdan za posadoyu viddaleno): Roz'yasnennya Nacionalnogo agentstva Ukrayini z pitan derzhavnoyi sluzhbi vid 20.03.2020 r. № 87-r/z [Regarding the implementation of changes to the Rules of Internal Procedure in a public authority (to perform tasks ex officio remotely) [electronic resource]: Clarification of the National Agency of Ukraine for Civil Service Affairs No. 87-r/z of 20.03.2020]. Retrieved from: https://blog.comfy.ua/ua/ top-11-khmarnikh-skhovishhvideooglyad-blog-comfy_a0-125/ (accessed 29 July 2021). 